\title{
PRELIMINARY PHYTOCHEMICAL SCREENING AND TO EVALUATE THE ANTHELMINTIC ACTIVITY OF HYDRO-ALCOHOLIC AND PETROLEUM ETHER EXTRACT OF NYCTANTHES ARBOUR-TRISTIS ROOT. (FAMILY-NYCTAGINACEAE)
}

\author{
AKM ABDULLAH*, SUMIT DAS \\ Girijananda Chowdhury Institute of Pharmaceutical Science Azara, Guwahati, India \\ Email: akmabdullah493aa@gmail.com
}

Received: 21 Apr 2018, Revised and Accepted: 10 Jun 2018

\begin{abstract}
Objective: To estimate the anthelmintic activity of hydro-alcoholic (methanol) and petroleum ether extract of Nyctanthes arbour-tristis (familyNyctaginaceae) in conjugation with phytochemical screening.

Methods: The hydro-alcoholic and petroleum ether extract of the whole root part of the plant Nyctanthes arbour-tristis (family-Nyctaginaceae) was prepared. And studies Phytochemical constitutes by the various standard method. The anthelmintic activity of the plant was performed by a different extract of plant material were tested against adult Indian earthworms pheretima posthuma as test worms, the bioassay determines the time of paralysis and time of death. Albendazole is used as a standard reference drug.
\end{abstract}

Results: The present study shows the phytochemical analysis, the anthelmintic activity of the hydro-alcoholic and petroleum ether extract of the root of Nyctanthes arbour-tristis. Various phytochemical analyses revealed the presence of alkaloids, carbohydrates, flavonoids, tannin, phenol," glycosides, saponins respectively. The anthelmintic activity of the plant extract showed significant results against all earthworms

Conclusion: The study has shown that petroleum ether and methanolic extract of Nyctanthes arbortristis root have significantly determined anthelmintic activity. But the methanolic extract of Nyctanthes arbortristis root shown most significant anthelmintic activity as compared to petroleum ether extract.

Keywords: Albendazole, Earthworms (pheretima posthuma), Nycthanthes arbor tristis, Anthelmintic activity

(c) 2018 The Authors. Published by Innovare Academic Sciences Pvt Ltd. This is an open access article under the CC BY license (http://creativecommons.org/licenses/by/4.0/) DOI: http://dx.doi.org/10.22159/ijcpr.2018v10i4.28469

\section{INTRODUCTION}

Nyctanthes arbor tristisis one of the well known and most useful medicinal plants. It is commonly called-Night jasminte [English], due to fact that its flowers emit a very strong and pleasant fragrance during the whole night. The flowers start falling after midnight and by the daybreak, the plant appears dull. The generic name -Nyctanthes \|has been coined from two Greek words Nykhta= (night) and Anth(lowers) . The specific name arbortristismeansas it loses its brightness during the daytime. NAT is a large shrub or a small tree widely cultivated in tropical and subtropical regions all over the world. Leaves, fruits, flowers, stem and barks have pharmacological activity. NATplant has been screened for anti-malarial anti-histaminic, activity, anti-arthritis activity, local anaesthetic, antihypnotic,analgesic, anti-ulcer, antipyretic, anti-depressant, anti-leishmaniasis, anti-cancer, antilarvicidal, antiallergic, anti-viral, Immunomodulatory, antihelminthic, antioxidant, anti-diuret. Therapeutic properties of medicinal plants have been used traditionally to treat human diseases. Growing populations of developing countries use plantderived medicines to be a normal part of primary health care. Hundreds to thousands of diverse secondary metabolites with different biological activities were found recorded in higher plants. In recent years, multiple drug resistance (MDR) human pathogenic microorganisms have developed due to the indiscriminate use of synthetic antimicrobial drugs commonly used in the treatment of infectious diseases [1,2].

\section{Introduction to helminthiasis}

Helminthiasis or worm infection is one of the most prevalent diseases. Many worms are parasitic in humans and cause a serious complication. It is estimated that one-fourth of the world population may be infected by worms. In Helminthiasis this organism multiply outside of the definitive host and have the unique ability to envade host immune defences, for reasons that are not fully understood.
Helminthiasis tends to be chronic, possibly lasting an entire lifetime of the host. Infected host humans are divided into two categories or phyla.

$>$ Platy helminthes(flatworms):-

In which a. Cestodes (tapeworms), b. Trematode (flukes) is included.

$>$ Nematodes (roundworms):-

In which a. Roundworm, b. Hookworm, c. Pinworm, d. Whipworm is included $[3,4]$.

\section{MATERIALS AND METHODS}

\section{Plant material and collection}

The root of Nyctanthes arbortristics have been collected from a local area of Guwahati (dist. kamrup) the root was dried at room temperature $\left(30-40^{\circ} \mathrm{C}\right)$. The plant was authenticated by Dr. P. P. Baruah, professor and head, Department of Botany, Gauhati University, Assam, India

\section{Worms Collection}

Indian earthworm Pheritimaposthuma (Annelida) were collected from the waterlogged areas of soils Indian earthworms are identified at Girijanandachowdhury institute of pharmaceutical science (Azara, Guwahati)

\section{Chemicals and reagents}

Petroleum Ether, Methanol, Dragondorff reagent, Mayer's reagent, Wagner's reagent, Benedict's reagent, sulphuric acid, lead acetate, Molisch's reagent, Fehling solution A and B, sodium citrate, copper sulphate, ferric chloride, sodium hydroxide, glacial acetic acid, benzene, chloroform, ammonia, nitric acid, potassium nitrite, gelatine, Albendazole suspension [Zentel, GSK Pharmaceuticals Ltd. Bangalore], and CMC [Rankem Lab.] were used during the experimental protocol. All the chemicals used are a laboratory and analytical grade. 


\section{Preparation of the plant extract}

The root of night flowering jasmine was collected and washed with tap water, remove all the soil and dirt's and shade dried. Shade-dried roots were grinded and formed powdered, then it passed through sieve number 60 and then the material was extracted with non-polar to polar solvents. At first, the plant material was defatted with petroleum ether then the extraction is carried out in a hydroalcoholic solvent that is methanol and distilled water in a Soxhlet apparatus by continuous heat extraction. The extract was concentrated in a rotary flash evaporator at a temperature not exceeding $50^{\circ} \mathrm{C}[5]$.

\section{Phytochemical screening}

\section{Test for alkaloids}

A fraction of extract was treated with3-5 drops of Wagner's reagent (1.27 $\mathrm{g}$ of iodine and $2 \mathrm{~g}$ of potassium iodide in $100 \mathrm{ml}$ of water) and observed for the formation of a reddish-brown precipitate.

\section{Test for tannins}

Two ml of the extract was treated with $10 \%$ alcoholic ferric chloride solution and observed for formation of blue or greenish colour solution.

\section{Test for saponins}

One $\mathrm{ml}$ aliquot of floral extract was combined with $5 \mathrm{ml}$ distilled water at $60^{\circ} \mathrm{C}$, shaken for $2 \mathrm{~min}$, as saponins are known to possess frothing activity, the volume of froth produced in this experiments was observed and recorded every $10 \mathrm{~min}$ for a period of $30 \mathrm{~min}$.

\section{Tests for glycosides}

To $2 \mathrm{ml}$ of the extract, added $3 \mathrm{ml}$ of $\mathrm{CHCl} 3$ and $10 \%$ ammonia solution. Formation of pink colour indicates the presence of glycosides.

\section{Test for carbohydrates (Molisch's test)}

Few drops of Molisch's reagent were added to $2 \mathrm{ml}$ of the methanolic floral extract. This was followed by addition of $2 \mathrm{ml}$ of conc. H2SO4 down the side of the test tube. The mixture was then allowed to stand for 2-3 min without shaking. Formation of a red or dull violet colour at the interphase of the two layers was a positive test. Test for proteins: One $\mathrm{ml}$ of methanolic extract was mixed with $2 \mathrm{ml}$ of millon's reagent. The appearance of a white precipitate which turned red upon gentle heating confirms the presence of protein. Test for alkaloids: A fraction of extract was treated with 3-5 drops of Wagner's reagent (1.27 g of iodine and $2 \mathrm{~g}$ of potassium iodide in $100 \mathrm{ml}$ of water) and observed for the formation of reddish-brown precipitate.

\section{Test for flavonoids}

The extract was dissolved in diluted $\mathrm{NaOH}$ and $\mathrm{HCl}$. A yellow solution that turns colourless indicates the presence of flavonoids.

\section{Test for proteins}

One $\mathrm{ml}$ of methanolic extract was mixed with $2 \mathrm{ml}$ of Millon's reagent. Appearance of a white precipitate which turned red upon gentle heating confirms the presence of protein.

\section{Test for phenolic compounds}

To $1 \mathrm{ml}$ of the extract, few drops of $0.5 \%$ ferric chloride solution were added. Formation of bluish black colour indicated the presence of phenolic compounds [6-8].

\section{Anthelmintic activity}

For the anthelmintic activity of Nyctanthesarbortristis, Indian adult earthworms (pheretimaposthuma) in $6 \mathrm{~cm}$ in length and $0.1-0.1-2 \mathrm{~cm}$ in width were used. The earthworms were divided into ten groups of six earthworms in each group. The extract was dissolved in DMSO in different concentrations and the final volume was adjusted to $10 \mathrm{ml}$; the extract and standard drugs were freshly prepared before starting the experiments. The extract of different concentration and standard solution were poured in different Petri dishes. All the earthworms were washed into normal saline solution before they are released into Petri dishes. Observation was made for the time taken to paralyze (paralysis was said to occur when earthworms didn't revive in normal saline) and death (death was concluded when earthworms lost their motility and followed with their body colors fading away).

\section{RESULTS}

The study shows the phytochemical screening, anthelmintic activity of the hydro-alcoholic and petroleum ether extract of the plant Nyctanthes arbortristis. The yield \% of the extraction of the hydroalcoholic was $4.65 \%$ and petroleum ether $4.88 \%$.

\section{Phytochemical screening}

Table number 1 showed the result of Phytochemical screening of both extract hydro-alcoholic and petroleum ether. Where the $(+)$ positive mean present and (-) negative mean absent.

\section{Anthelmintic activity}

Table number 2 showed the anthelmintic activity of the plant extract. The hydro-alcoholic and petroleum ether extract of the Nyctanthes arbortristis root having anthelmintic activity against earthworms (pheretima posthuma)

Table 1: Phytochemical screening of hydro-alcoholic and petroleum ether extract of root of $\mathrm{Nyctanthes}$ arbortristis

\begin{tabular}{lll}
\hline Chemical test & Pet. ether & Hydro alcoholic \\
\hline Alkaloid & -ve & -ve \\
Tannins & + +ve & + ve \\
Saponins & $+\mathrm{ve}$ & $+\mathrm{ve}$ \\
Glycoside & $+\mathrm{ve}$ & $+\mathrm{ve}$ \\
Carbohydrates & $-\mathrm{ve}$ & $-\mathrm{ve}$ \\
Flavonoids & $+\mathrm{ve}$ & $+\mathrm{ve}$ \\
Proteins and amino acid & $+\mathrm{ve}$ & $+\mathrm{ve}$ \\
Phenolics & $+\mathrm{ve}$ & $+\mathrm{ve}$ \\
\hline
\end{tabular}

(+ve) Presence, (-ve) Absence

Table 2: Antimicrobial activity of root hydro-alcoholic and petroleum ether extract Nyctanthes arbortristis observed against the earthworms

\begin{tabular}{llll}
\hline Groups & Dose $\mathbf{( m g / m l )}$ & Time for paralysis(min) & Time for death (min) \\
\hline Control & -- & -- & - \\
Standard(Albendazole) & 50 & 14.43 & 20 \\
& 100 & 10 & 15.4 \\
Petroleum ether & 200 & 6.62 & 9.51 \\
& 50 & 16.09 & 21.4 \\
& 100 & 12.2 & 17.3 \\
Methanolic extract & 200 & 8.5 & 13.9 \\
& 50 & 10.09 & 15.35 \\
& 100 & 7.14 & 12.24 \\
\hline
\end{tabular}




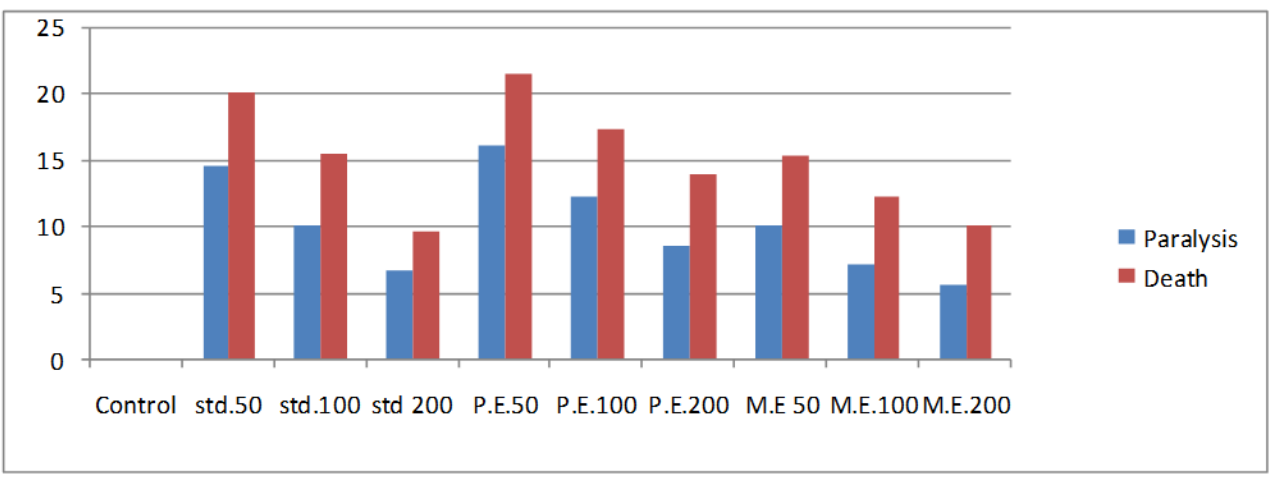

Fig. 1: Paralysis vs death of different extract

\section{DISCUSSION}

\section{Phytochemical analysis}

The Phytochemical test of Nyctanthes arbortristis root showed the presence of various phytoconstituents. Hydro-alcoholic extract and petroleum ether having Carbohydrates, Flavanoids, Tannin, Phenol, Glycosides, Saponins and Alkaloids, Saponins (table 1).

\section{Anthelmintic activity}

In the present study, it was observed that all the extracts of nyctanthes arbor tristisroot root have exhibited a positive response to the certain degree of anthelmintic activity. Extracts exhibited more potent activity at higher concentration $(200 \mathrm{mg} / \mathrm{ml})$ against Pheretimaposthuma (earthworm). Evaluation of anthelmintic activity was compared with reference standard Albendazole as shown in table 2 and plot the graph for comparison of different extract (fig. 1)

\section{CONCLUSION}

The study has shown that petroleum ether and methanolic extract of Nyctanthesarbortristisroot have significantly determined anthalmintic activity. But the methanolic extract of Nyctanthesarbortristis leaves shown most significant anthelmintic activity as compared to petroleum ether extract. Further studies can be done to identify the possible phyto constituents responsible for the anthelmintic action. In conclusion the traditional use of plant

\section{ACKNOWLEDGEMENT}

The authors thankful to Mr. Sumit Das, Assistant Professor Department of Pharmaceutical Chemistry, Girijananda Chowdhury Institute of Pharmaceutical Science, Guwahati, India for his guidance given during this work and Principal for conveying this exploration work.

\section{AUTHORS CONTRIBUTIONS}

All the author have contributed equally

\section{CONFLICT OF INTERESTS}

Declare none

\section{REFERENCES}

1. Hamburger M, Hostettmann K. Biochemistry in plants: the link between phytochemistry and medicine. Phytochemicals 1991;30:3864-7.

2. Singh BR, Singh V, Ebibeni N, Singh RK. Antimicrobial and herbal drug resistance in enteric bacteria isolated from faecal droppings of common house lizard/gecko (Hemidactylus frenatus). Int J Microbiol 2013;13:340-848.

3. Perry BD, Randolph TF. In: Veterinary, Parasetology: International livestock, Research institute, Nairobi, Kenya; 1999. p. 84, 145.

4. Goodman and Gilman's, The Pharmacological Basis of Therapeutics, Tenth Edition, International edition; 2001. p. 1121-37.

5. Kurian S, Josekumar VS. Phytochemical screening, antimicrobial activity and brine shrimp lethality bioassay of different extracts of Alysicarpus vaginalis var. nummularifolius (DC.) MIQ. (family: fabaceae). Int J Pharm Sci 2017;9:1-6.

6. Dilla Jose, S Pandiammal. Journal of Academia and Industrial Research; 2016. p. 2278-5213.

7. Kokate CK. Pharmacognosy. Nirali Publication; 2007. p. 97-132.

8. Woisky R, Salatino. Screening of Indian plants for biological activity. Part II. A. J Agric Res 1998;37:99-105. 